\title{
Titulo: Implantação de um Programa Permanente de Humanização de Atendimento À Saúde do Usuário e do Profissional de Saúde
}

\author{
Guerra, Roberta Sannomya \\ Hospital de Caridade São Vicente de Paulo — roberta.guerra@hsvicente.org.br
}

INTRODUÇÃO: o Programa de Humanização foi descrito a partir da mudança na Gestão Administrativa de um Hospital Geral de alta complexidade, localizado no interior de São Paulo em Agosto de 2013. a evolução do conhecimento técnico científico não tem sido acompanhada por um correspondente avanço na qualidade do contato humano presente em toda a intervenção de atendimento à saúde. Existe a urgência em associar a competência técnica e a competência na relação, fazendo-se necessário o resgate da dimensão subjetiva na intervenção em saúde. OBJETIVO: Trabalho de natureza subjetiva e personalizada, direcionado a educar os profissionais da saúde e gestores à conscientização de uma cultura hospitalar humanizada. Busca-se o alcance de ações capazes de atender as três dimensões, humanização do atendimento ao usuário; humanização das condições de trabalho do profissional da saúde e humanização do atendimento da instituição hospitalar em suas necessidades básicas administrativas, físicas e humanas. METODOLOGIA: o programa foi dividido em sete etapas de execução, sendo essas - Estabelecimento da comissão de humanização, reconhecido como espaço coletivo e democrático, de escuta e análises; Treinamentos direcionados a ampliar consciência e despertar sensibilidade para o tema; Formação de grupo de trabalhos setorizados; Realização do Diagnóstico situacional, mapeamento das potencialidades e deficiências de cada setor; Elaboração e implantação de plano operacional; Execução e implantação das ações de humanização; Avaliação permanente dos resultados. RESULTADOS: o programa é direcionado para o alcance de $75 \%$ dos profissionais da saúde da instituição hospitalar, ampliando responsabilização e adoção da ética do cuidado gerando resultados positivos para o paciente, além do desenvolvimento e definição de ações permanentes como ferramentas da divulgação da cultura humanizada, tornando os processos seguros, aumentando a eficiência na resolução dos conflitos e favorecendo a qualidade na comunicação. no decorrer destes cinco meses, desde implantação do projeto, diversas ações foram desenvolvidas, iniciaram treinamentos ao quadro de recursos humanos e o tema humanização está sendo explorado como condição sine qua non ao exercício profissional e cuidados prestados ao paciente. CONCLUSÃO: a implantação deste programa e permanência de suas ações fomentam as prerrogativas e diretrizes da Política Nacional de Humanização, estabelecendo qualidade na assistência integrada, propiciando gestão administrativa humanizada que valoriza, atende as necessidades humanas e respeita a equidade das relações.

Guerra, Roberta Sannomya. Titulo: Implantação de um Programa Permanente de Humanização de Atendimento À Saúde do Usuário e do Profissional de Saúde.. In: Anais do Congresso Internacional de Humanidades \& Humanização em Saúde [= Blucher Medical Proceedings, num.2, vol.1]. São Paulo: Editora Blucher, 2014. ISSN 2357-7282

DOI 10.5151/medpro-cihhs-10271 